\title{
Interferon alpha and rapamycin inhibit the growth of pheochromocytoma PC12 line in vitro
}

\author{
Interferon alfa i rapamycyna hamują wzrost linii komórkowej \\ pheochromocytoma PC12 w warunkach in vitro

\section{Ewelina Motylewska $^{1^{*}}$, Hanna Lawnicka ${ }^{1 *}$, Magdalena Kowalewicz-Kulbat ${ }^{2}$, Paulina Sicinska ${ }^{3}$, Agata Niedziela', Gabriela Melen-Mucha' ${ }^{1}$, Henryk Stepien ${ }^{1}$}

${ }^{1}$ Department of Immunoendocrinology, Chair of Endocrinology, Medical University of Lodz, Poland

${ }^{2}$ Department of Immunology and Infectious Biology, University of Lodz, Lodz, Poland

${ }^{3}$ Department of Environmental Pollution Biophysics, University of Lodz, Lodz, Poland

${ }^{*}$ E. Motylewska and H. Lawnicka contributed equally to this work

\begin{abstract}
Introduction: Pheochromocytomas are benign or malignant neuroendocrine tumours. The unsatisfactory efficacy of the traditional therapeutic methods for patients with metastatic disease results in a continuing search for more effective and targeted agents. Due to the increased vascularisation of these tumours, inhibitors of angiogenesis could be potentially a new group of drugs in pheochromocytoma/ /paraganglioma therapy.

Material and methods: The aim of this study was to evaluate the influence of angiomodulators: VEGF (vascular endothelial growth factor) and five endogenous and exogenous antiangiogenic compounds (endostatin; IFN- $\alpha$ [interferon alpha]; rapamycin - mTOR [mammalian target of rapamycin] inhibitor; JV1-36 and SU5416 (semaxinib]) on the growth of rat pheochromocytoma PC12 cell line.

Results: IFNa $\left(10^{5} \mathrm{U} / \mathrm{mL}\right)$ strongly inhibited PC12 growth in a $72 \mathrm{~h}$ culture, increasing apoptosis and arresting the cell cycle. Rapamycin in a wide range of concentrations $\left(10^{-5}\right.$ to $\left.10^{-8} \mathrm{M}\right)$ induced a slight inhibitory effect on PC12 viability and decreased cell proliferation at the concentration of $10^{-5} \mathrm{M}$. VEGF, endostatin and JV1-36 did not influence the growth of PC12.

Conclusions: The study has shown for the first time that IFN- $\alpha$ inhibited the growth of pheochromocytoma PC12 line and confirmed the inhibitory action of rapamycin on these cells. The results suggest that IFN- $\alpha$ and mTOR inhibitors could be potentially effective in the therapy of malignant pheochromocytoma, and encourage further study in this field.

(Endokrynol Pol 2013; 64 (5): 368-374)
\end{abstract}

Key words: pheochromocytoma, interferon alpha, rapamycin, antiangiogenic factors, PC12 line

\section{Streszczenie}

Wstęp: Guzy chromochłonne (pheochromocytoma/paraganglioma) należą do łagodnych lub złośliwych nowotworów neuroendokrynnych. Wobec niezadowalającej skuteczności standardowych sposobów leczenia pacjentów z rozsianą postacią choroby, wciąż poszukuje się nowych metod terapii, $w$ tym możliwości skutecznego leczenia celowanego. W związku ze wzmożonym unaczynieniem tych nowotworów, preparaty o działaniu antyangiogennym mogą potencjalnie stanowić nową grupę leków stosowanych w leczeniu pheochromocytoma/paraganglioma. Materiał i metody: W badaniu oceniano wpływ różnych angiomodulatorów: VEGF (naczyniowo-środbłonkowy czynnik wzrostu) oraz pięciu endo- i egzogennych czynników antyangiogennych (endostatyna; IFN- $\alpha$ [interferon alfa]; rapamycyna — inhibitor szlaku mTOR [mammalian target of rapamycin]; JV1-36 and SU5416 [semaxinib]) na wzrost szczurzej linii pheochromocytoma PC12.

Wyniki: IFN- $\alpha\left(10^{5} \mathrm{U} / \mathrm{mL}\right)$ silnie hamował wzrost komórek PC12 w hodowli 72 h, nasilając apoptozę i hamując cykl komórkowy. Rapamycyna w szerokim zakresie stężeń $\left(10^{-5}\right.$ to $\left.10^{-8} \mathrm{M}\right)$ nieznacznie zmniejszała żywotność komórek PC12, a w stężeniu $10^{-5} \mathrm{M}$ także hamowała ich proliferację. VEGF, endostatyna oraz JV1-36 nie wpływały na wzrost lini PC12.

Wnioski: W badaniu po raz pierwszy wykazano, że IFN- $\alpha$ hamuje wzrost linii komórkowej pheochromocytoma PC12, a także potwierdzono hamujący wpływ rapamycyny wobec tej linii komórkowej. Uzyskane wyniki sugerują zatem, że IFN- $\alpha$ oraz inhibitory szlaku mTOR mogą być potencjalnie skuteczne w leczeniu złośliwych postaci guzów chromochłonnych i zachęcają do dalszych badań w tym kierunku. (Endokrynol Pol 2013; 64 (5): 368-374)

Słowa kluczowe: pheochromocytoma, interferon alpha, rapamycyna, czynniki antyangiogenne, linia PC12

This work has been supported by a contribution from the Medical University of Lodz, Grant No. 503/1-153-03/503-1.

\section{Introduction}

Pheochromocytoma and paraganglioma are numbered among neuroendocrine tumours (NETs). They can occur sporadically or as a part of familial syndrome, and can be benign or malignant tumours [1]. Gene mutations often observed in these tumours are part of two distinct molecular pathways: cluster 1 (mutations of $V H L, S D H B$

Prof. Henryk Stepien M.D., Ph.D., Department of Immunoendocrinology, Chair of Endocrinology, Medical University of Lodz, Dr Sterling St. 3, 91-425 Lodz,

Poland, tel/fax: +48 42632 4854, e-mail: hstep@csk.umed.lodz.pl 
and $S D H D$ ) leading to overexpression of angiogenic factors; and cluster 2 (mutations of RET, NF1, TMEM127, and $M A X)$ associated with abnormal activation of kinase signalling pathways such as PI3kinase/AKT, mTOR1/p70s6K and RAS/RAF/ERK, leading to abnormal cell growth and lack of apoptosis capacity* [2]. These signalling alterations promote tumourigenesis, as hyperactivity of mTOR pathway is a well established factor leading to different neoplasms [3] and increased angiogenesis has been shown to be associated with the development of metastases, poor prognosis and reduced survival in many tumours [4]. The invasiveness of pheochromocytoma also correlated with the number of tumour blood vessels and increased VEGF (vascular endothelial growth factor) immunoreactivity [5]. The importance of VEGF for the angiogenesis of pheochromocytomas has also been demonstrated in in vitro studies [6]. Moreover, malignant pheochromocytomas are characterised by increased expression of several other proangiogenic factors [7]. The traditional therapeutic methods (surgery, 131I-MIBG (metaiodobenzylguanidine), chemotherapy) for patients with metastatic pheochromocytoma/paraganglioma are limited and often ineffective $[2,8,9]$. Thus, better understanding of specific molecular pathways alteration in the development of pheochromocytoma/paraganglioma might lead to molecular-targeted therapy, using antiangiogenic agents and mTOR inhibitors.

Therefore, this paper aims to study the direct influence of proangiogenic (VEGF) and antiangiogenic (rapamycin, interferon alpha, endostatin, JV1-36, SU5416) compounds on the growth of rat pheochromocytoma PC12 cell line. The PC12 cell, a clonal cell line derived from a pheochromocytoma of the rat adrenal medulla, seems to be an excellent experimental model for studying the influence of exogenous angiogenic modulators on the growth and functional activity of neuroendocrine adrenal chromaffin cells.

Rapamycin, a naturally occurring macrolide antibiotic, was the first known inhibitor of PI3K/AKT/ /mTOR-pathway, which was initially discovered as an antifungal drug and immunosuppressive agent. The antiangiogenic and antitumour activity of rapamycin was found later $[3,10]$ and gave rise to the use of mTOR inhibition in cancer treatment, which has proved to be effective in a number of neoplasms [3], including neuroendocrine tumours [11]. In 2011, the FDA (Food and Drug Administration) approved an mTOR inhibitor, everolimus, for the treatment of progressive pancreatic neuroendocrine tumours (PNETs) (NCI; http://www. cancer.gov/cancertopics/druginfo/fda-everolimus).
JV1-36 belongs to GHRH (growth hormone releasing hormone) antagonists, which have been shown to exert antiproliferative effects in different tumours. The mechanism of GHRH antagonist action is complex and apart from inhibition of IGFs (insulin-like growth factors) production, the suppression of VEGF and bFGF (basic fibroblast growth factor) expression in neoplasms is suggested [12].

SU5416 (semaxinib), a 3-substituted indolinone compound, was the first VEGFR (vascular endothelial growth factor receptor) tyrosine kinase inhibitor tested clinically as antiangiogenic treatment in cancer [13].

Endostatin is a proteolytic fragment of collagen XVII. It is an endogenous inhibitor of angiogenesis which also exerts an antineoplastic action [14, 15]. Although endostatin suppressed the growth of pancreatic neuroendocrine tumour in transgenic RT2 (RIP-Tag2) mice [16], the clinical study did not confirm the effectiveness of endostatin in PNET treatment [17].

Interferon alpha (IFN- $\alpha)$ is a pleiotropic cytokine with proven antitumour activity. The antineoplastic effect of IFN- $\alpha$ is triggered in direct (prolongation of the cell cycle time and enhancement of apoptosis in malignant cells), and indirect (interaction with other cytokines, immunomodulatory and antiangiogenic influence), mechanisms [18). IFN- $\alpha$ as an angiogenesis inhibitor was first reported in 1980 [19] and then was confirmed by other authors [18, 20]. The clinical use of IFN- $\alpha$ includes treatment of renal cell carcinoma, melanoma, neuroendocrine tumours and some other neoplasms [18].

\section{Material and methods}

\section{Cell line and culture condition}

The rat pheochromocytoma cell line PC12 obtained from the American Type Culture Collection (ATCC) was used in the experiments. The cells were routinely grown as a monolayer in a humidified incubator at $37 \mathrm{C}$ with $5 \% \mathrm{CO}_{2}$ in F12-K medium (ATCC), supplemented with $100 \mathrm{U} / \mathrm{mL}$ penicillin and $100 \mu \mathrm{g} / \mathrm{mL}$ streptomycin solution (Sigma), $15 \%$ horse serum (ATCC) and 2.5\% fetal bovine serum (Biochrom). The cells were passaged every seven days with $0.05 \%$ trypsin $/ 0.02 \%$ EDTA (Trypsin-EDTA, Sigma) and the medium was changed every $3-4$ days.

\section{Substances}

The following substances were used in the experiments: mouse IFN- $\alpha$ (Sigma), rapamycin (Sigma), JV1-36 (Bachem), SU5416 (Sigma), mouse endostatin (Sigma), mouse VEGF (Sigma).

\footnotetext{
*(VHL — von Hippel Lindau, SDHB and SDHD — subunits B and D of the succinate dehydrogenase (SDH); RET — rearranged during transfection; NF1 - Neurofibromatosis type I; TMEM127 — transmembrane protein 127; MAX — MYC associated factor X; PI3kinase/AKT — phosphatidylinositol 3-kinase/protein kinase B; mTOR1/p70s6K - mammalian target of rapamycin/p70 ribosomal S6 kinase; RAS/RAF/ ERK - cascade of extracellular signal-regulated kinase)
} 
IFN- $\alpha$, JV1-36, endostatin and VEGF were diluted in serum free culture medium and added to the appropriate wells at the final concentrations as indicated in figures. The control group in these experiments received medium.

Rapamycin was dissolved in $96 \%$ ethanol and serum free culture medium (5\% of $96 \%$ ethanol in stock solution) and added to the appropriate wells at the final concentrations as indicated in figures. The appropriate volume of serum free culture medium and $96 \%$ ethanol at the final concentration identical with the solvent concentration in $10^{-5} \mathrm{M}$ group was added to the control wells.

SU5416 was dissolved in DMSO and serum free culture medium (10\% of DMSO in stock solution) and added to the appropriate wells at the final concentrations as indicated in figures. The appropriate volume of serum free culture medium and DMSO at the final concentration identical with the solvent concentration in every examined group was added to the control wells.

The action of all the agents in a wide range of concentrations was determined using an MTT colorimetric assay. Following this, based on the results of the MTT study, some concentrations of the substances were further assessed using the BrdU incorporation method, cell cycle analysis and apoptosis examination. However, the MTT method was not used to estimate the influence of SU5416 on PC12 cell growth because of the potential interference of this yellow-dyeing compound with the manufacturer's procedures.

\section{Cell viability/cytotoxicity study/Mosmann method}

The MTT (3-(4,5-dimethylthiazol-2-yl)-2,5-diphenyltetrazolium bromide) colorimetric assay was used as an indicator of cell viability/cytotoxicity. PC12 cells were seeded at a density of $10 \times 10^{3}$ cells/well into 96-well microplates in $180 \mu \mathrm{L} /$ well of complete culture medium. After preincubation $(24 \mathrm{~h})$, the cells were cultured for a further $72 \mathrm{~h}$ in the presence of various concentrations of the examined substances $(20 \mu \mathrm{L}$ : IFN- $\alpha$, rapamycin, JV1-36, endostatin, VEGF). Cell viability was assessed using the EZ4U assay kit (The 4th Generation Non Radioactive Cell Proliferation \& Cytotoxity Assay, Biomedica Gesellschaft $\mathrm{mbH}$, Biomedica Gruppe, Austria) according to the manufacturer's instructions. The optical density (OD) of each sample was measured by a microplate reader at $450 \mathrm{~nm}$.

\section{Cell proliferation study}

Colorimetric immunoassay based on the measurement of 5-bromo-2'-deoxyuridine (BrdU) incorporation during DNA synthesis was used for the quantification of PC12 cell proliferation. PC12 cells were seeded at a density of $10 \times 10^{3}$ cells/well into 96-well microplates in $90 \mu \mathrm{L} /$ well of complete culture medium. After pre- incubation $(24 \mathrm{~h})$, the cells were cultured for a further $72 \mathrm{~h}$ in the presence of various concentrations of the examined substances (10 $\mu \mathrm{L}$ : IFN- $\alpha$, rapamycin, JV1-36, SU5416, endostatin, VEGF). Cell proliferation was assessed using the BrdU assay (Cell proliferation ELISA, BrdU, Roche) following the producer's instructions. The optical density (OD) of each sample was measured by a microplate reader at $450 \mathrm{~nm}$.

\section{Cell cycle analysis}

PC12 cells were seeded at a density of $3 \times 10^{5}$ cells/well into six-well microplates in $1,350 \mu \mathrm{L} /$ well of complete culture medium. After preincubation $(24 \mathrm{~h})$, the cells were cultured for a further $72 \mathrm{~h}$ in the presence of various concentrations of the examined substances $(150 \mu \mathrm{L}$ : IFN- $\alpha$, rapamycin). After $72 \mathrm{~h}$ of incubation, cells were harvested by gentle trypsynisation, centrifuged, resuspended in 100 $\mu \mathrm{L}$ of phosphate-buffered calcium and magnesium free saline (PBS), and fixed in $70 \%$ ice-cold ethanol. After centrifugation at $4^{\circ} \mathrm{C}$, the cells were finally suspended in PBS containing $75 \mu \mathrm{mol} / \mathrm{dm}^{3}$ propidium iodide (PI) and 50 IU Kunitz/mL of DNase-free RNase (Sigma Aldrich). After $30 \mathrm{~min}$ of incubation, the cell counts were taken with an LSR II Flow Cytometer (Becton Dickinson). The percentage of cells in G1, S and G2/M phases of the cell cycle and the percentage of cells undergoing apoptosis were determined with FlowJo analytical software.

\section{Apoptosis induction assay}

PC12 cells were seeded at a density of $3 \times 10^{5}$ cells/well into six-well microplates (NUNC, Denmark) in 1,350 $\mu \mathrm{L} /$ /well of complete culture medium. After preincubation (24 $\mathrm{h}$ ), the cells were cultured for a further $72 \mathrm{~h}$ in the presence of various concentrations of the examined substances (150 $\mu \mathrm{L}$ : IFN- $\alpha$, rapamycin). Apoptosis was measured using flow cytometry to quantify the levels of detectable phosphatidylserine on the outer membranes of apoptotic cells. Fluorescein isothiocyanate (FITC) Annexin-V Apoptosis Detection Kit (Becton Dickinson, San Jose, CA, USA) was used for the differentiation of apoptotic and necrotic cells. Briefly, after $72 \mathrm{~h}$ of incubation, cells were harvested by gentle trypsynisation and washed with cold PBS. The cells were resuspended in $1 \mathrm{~mL}$ of $1 \times$ binding buffer. One hundred microlitres were transferred to a $5 \mathrm{~mL}$ culture tube, and $5 \mu \mathrm{L}$ of Annexin V-FITC and $5 \mu \mathrm{L}$ of propidium iodide (PI) were added. Cells were vortexed and incubated for $15 \mathrm{~min}$ in the dark at room temperature. Next, $400 \mu \mathrm{L}$ of $1 \times$ binding buffer was added to each tube. Flow cytometric analysis was performed immediately after staining. Annexin-V/PI fluorescence was analysed for each sample; the fluorescence of 10,000 cells was gated and counted using FlowJo software. Early apoptotic cells were identified as PI negative, FITC Annexin V positive, whereas cells in the late stages of apoptosis were positive for both annexin $\mathrm{V}$ and PI. 


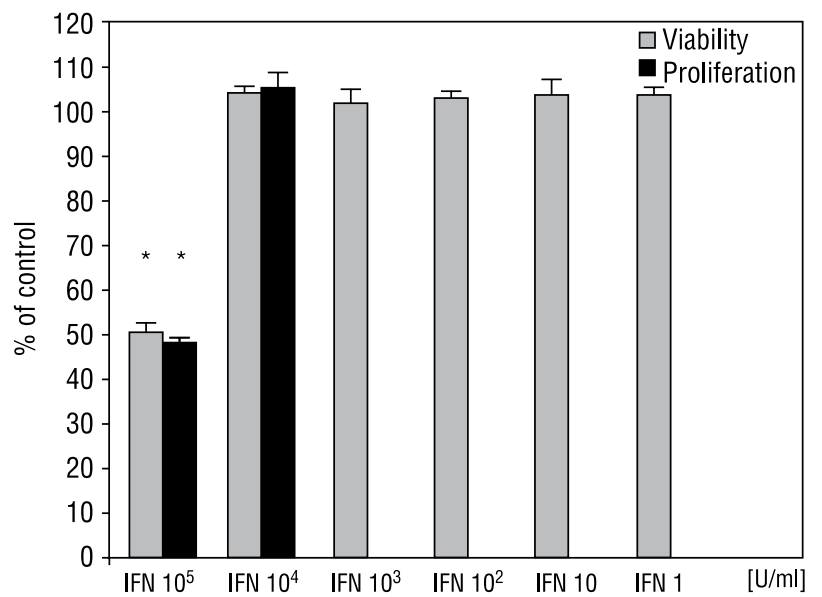

Figure 1. The effect of interferon alpha (IFN) on the growth of the PC12 pheochromocytoma cell line assessed by Mosmann and BrDU incorporation methods in $72 \mathrm{~h}$ culture. $X \pm$ S.E.M., ${ }^{*} p<0.05$ v. control

Rycina 1. Wptyw interferonu $\alpha$ (IFN) na wzrost komórek linii guza chromochtonnego PC12 oceniany metoda Mosmanna i wbudowywania BrDU w hodowli 72 h. X \pm S.E.M., ${ }^{*} p<0.05$ v. kontrola

Table I. The effect of interferon alpha (IFN $10^{5} \mathrm{U} / \mathrm{mL}$ ) and rapamycin $\left(R A P 10^{-5} \mathrm{M}\right)$ on the apoptosis of PC12 cells in 72 h culture

Tabela I. Wptyw interferonu $\alpha\left(\right.$ IFN $\left.10^{5} \mathrm{U} / \mathrm{mL}\right)$ i rapamycyny $\left(R A P 10^{-5} \mathrm{M}\right)$ na apoptozę komórek linii guza chromochłonnego PC12 $w$ hodowli $72 \mathrm{~h}$

\begin{tabular}{llll}
\hline & Viability & Apoptosis & Necrosis \\
\hline Control & $91.7 \%$ & $6.1 \%$ & $2.1 \%$ \\
\hline RAP & $88.8 \%$ & $8.0 \%$ & $3.2 \%$ \\
\hline IFN & $79.3 \%$ & $17.1 \%$ & $3.6 \%$ \\
\hline
\end{tabular}

\section{Statistical analysis}

The results of cell viability and cell proliferation are expressed as the average percentage of the optical density (OD) of the control groups. Comparisons of individual groups were evaluated by analysis of variance (oneway ANOVA) following LSD test (Least Significant Difference). Differences were considered significant if $p<0.05$. The results of cell cycle and apoptosis analysis are expressed as mean percentage of number of cells in G1, S and G2 phases or as percentage of apoptotic cells, respectively.

\section{Results}

IFN- $\alpha$ at the highest concentration of $10^{5} \mathrm{U} / \mathrm{mL}$ strongly inhibited PC12 growth in $72 \mathrm{~h}$ culture, up to $50 \%$ of the control group in MTT method (Fig. 1) and up to $47 \%$ of the control group in BrdU incorpo-

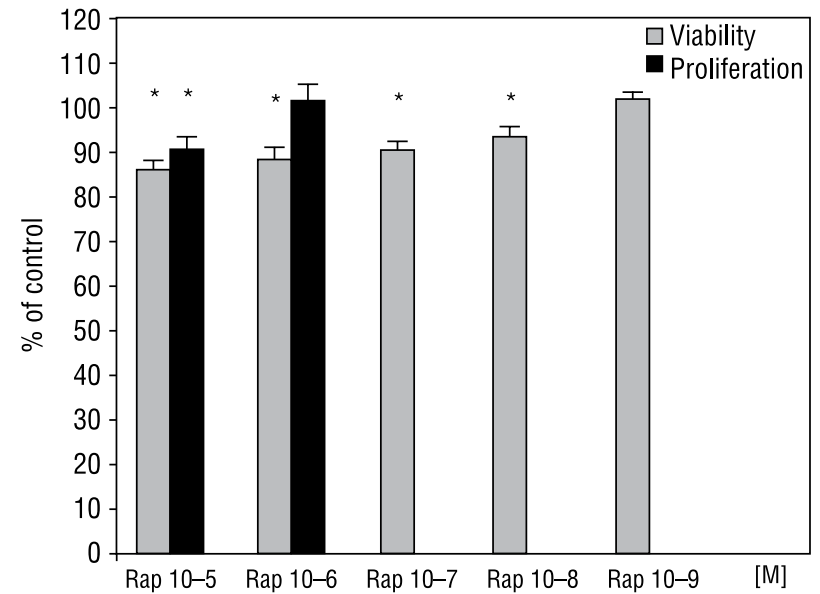

Figure 2. The effect of rapamycin (Rap) on the growth of the PC12 pheochromocytoma cell line assessed by Mosmann and $\mathrm{BrDU}$ incorporation methods in $72 \mathrm{~h}$ culture. $X \pm$ S.E.M., ${ }^{*} p<0.05$ v. control

Rycina 2. Wptyw rapamycyny (Rap) na wzrost komórek linii guza chromochtonnego PC12 oceniany metoda Mosmanna $i$ wbudowywania BrDU w hodowli 72 h. X \pm S.E.M., ${ }^{*} p<0.05$ v. kontrola

Table II. The effect of interferon alpha (IFN $10^{5} \mathrm{U} / \mathrm{mL}$ ) and rapamycin (RAP $\left.10^{-5} \mathrm{M}\right)$ on the cell cycle of PC12 cells in 72 h culture

Tabela II. Wptyw interferonu $\alpha\left(\right.$ IFN $\left.10^{5} \mathrm{U} / \mathrm{mL}\right)$ i rapamycyny (RAP $\left.10^{-5} \mathrm{M}\right)$ na cykl komórkowy linii guza chromochłonnego PC12 $w$ hodowli $72 \mathrm{~h}$

\begin{tabular}{llll}
\hline & Control & RAP & IFN \\
\hline G1 & $63.5 \%$ & $66.4 \%$ & $72.3 \%$ \\
\hline S & $21.7 \%$ & $18.3 \%$ & $8.9 \%$ \\
\hline G2 & $12.6 \%$ & $15.5 \%$ & $19.1 \%$ \\
\hline
\end{tabular}

ration method (Fig. 1). At this concentration, IFN- $\alpha$ increased apoptosis up to $17.1 \%$ of PC12 cell $(2.7 \%$ cells in early apoptosis and $14.4 \%$ cells in late apoptosis) $v .6 .1 \%$ of cells in the control group $(1.7 \%$ cells in early apoptosis and $4.4 \%$ cells in late apoptosis) (Fig. 3 and Table I). IFN- $\alpha$ at the concentration of $10^{5} \mathrm{U} /$ $\mathrm{mL}$ induced G0/G1 phase arrest (Fig. 4 and Table II).

Rapamycin at many concentrations $\left(10^{-5}\right.$ to $\left.10^{-8} \mathrm{M}\right)$ slightly inhibited PC12 cell viability (up to $86-93 \%$ of the control group) (Fig. 2). However, in the cell proliferation assay, only the highest concentration of rapamycin $\left(10^{-5}\right.$ M) was shown to be active ( $90 \%$ of the control group) (Fig. 2). Rapamycin did not induce apoptosis or influence cell cycle in a statistically dependent manner (Figs. 3-4, Tables I-II).

SU5416 at the concentration of $10^{-5} \mathrm{M}$ inhibited BrdU incorporation in PC12 cells up to $86 \%$ of the control group (Fig. 5). 


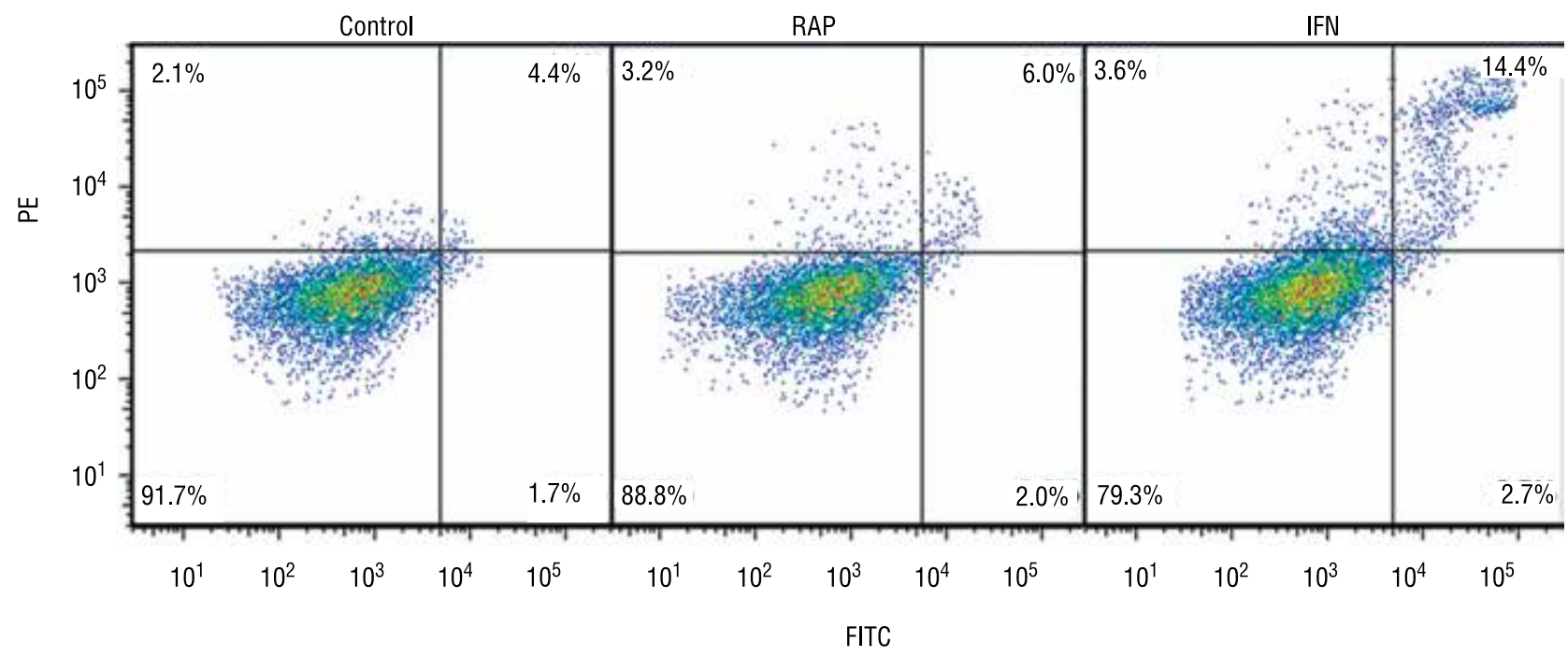

Figure 3. The effect of interferon alpha (IFN $\left.10^{5} \mathrm{U} / \mathrm{mL}\right)$ and rapamycin $\left(R A P 10^{-5} \mathrm{M}\right)$ on the apoptosis of PC12 cells in $72 \mathrm{hculture}$ Rycina 3. Wptyw interferonu a (IFN $\left.10^{5} \mathrm{U} / \mathrm{mL}\right)$ i rapamycyny $\left(R A P 10^{-5} \mathrm{M}\right)$ na apoptozę komórek linii guza chromochtonnego PC12 whodowli $72 \mathrm{~h}$

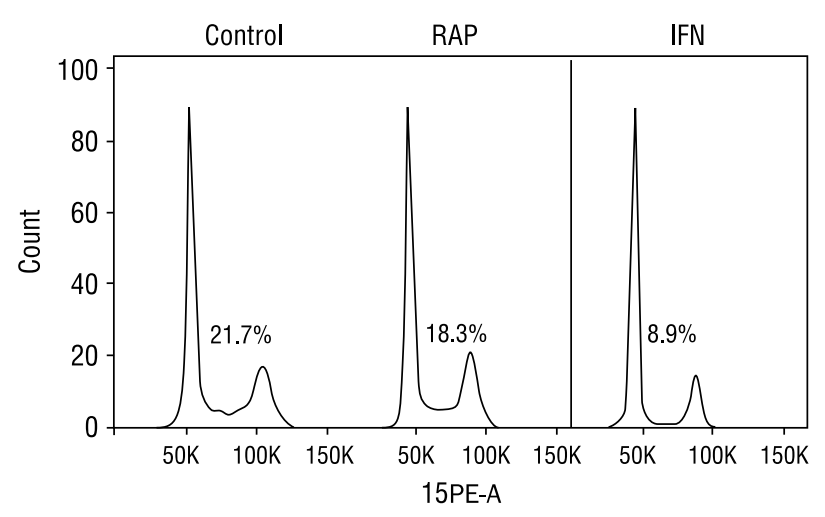

Figure 4. The effect of interferon alpha (IFN $10^{5} \mathrm{U} / \mathrm{mL}$ ) and rapamycin $\left(R A P 10^{-5} \mathrm{M}\right)$ on cell cycle phase distribution of $P C 12$ cells in $72 \mathrm{~h}$ culture

Rycina 4. Wptyw interferonu $\alpha$ (IFN $10^{5} \mathrm{U} / \mathrm{mL}$ ) i rapamycyny (RAP $10^{-5} \mathrm{M}$ ) na cykl komórkowy linii guza chromochłonnego PC12 w hodowli $72 \mathrm{~h}$

From all studied concentrations of JV1-36 $\left(10^{-5}, 10^{-6}\right.$, $\left.10^{-7}, 10^{-8}, 10^{-9}, 10^{-10} \mathrm{M}\right)$, only the highest concentration slightly (up to $92 \%$ of the control group), but statistically insignificantly, inhibited the growth of PC12 cells in Mosmann method (data not shown).

Endostatin (at the concentrations of $30 ; 15 ; 7.5 ; 3.75$; $1.875 ; 0.9375 \mu \mathrm{g} / \mathrm{mL}$ ) and VEGF (at the concentrations of $100 ; 50 ; 25 ; 12.5 ; 6.25 ; 3.125 ; 1.5625 \mathrm{ng} / \mathrm{mL}$ ) did not evoke inhibition of PC12 growth (data not shown).

\section{Discussion}

This paper aims to study the influence of interferon a mTOR inhibitor (rapamycin), VEGF receptor antago-

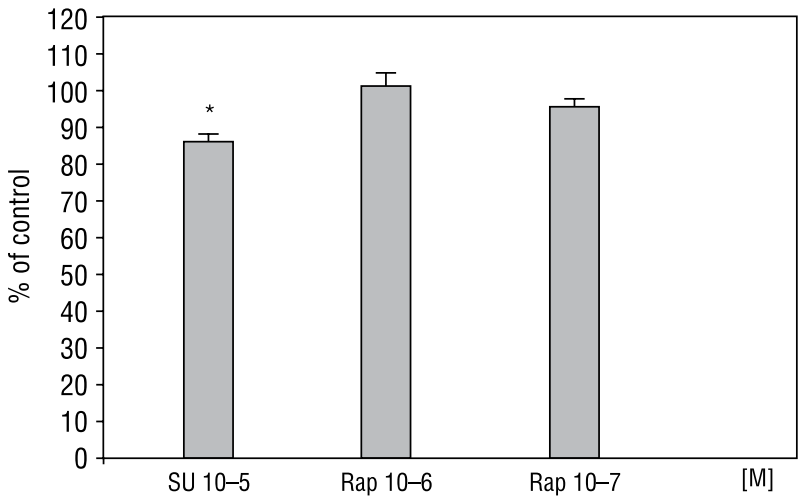

Figure 5. The effect of SU5416 on the growth of the PC12 pheochromocytoma cell line assessed by BrDU incorporation method in $72 h$ culture. $X \pm$ S.E.M., ${ }^{*} p<0.05$ vs. control

Rycina 5. Wptyw SU5416 na wzrost komórek linii guza chromochtonnego PC12 oceniany metoda wbudowywania BrDU w hodowli 72 h. X \pm S.E.M., ${ }^{*} p<0.05$ v. kontrola

nist (SU5416), GHRH receptor antagonist (JV1-36) and endostatin on pheochromocytoma growth, as these factors have been shown to reduce vascularisation and cell proliferation of different solid tumours. Moreover, the presence of specific molecular pathway alteration in pheochromocytoma/paraganglioma additionally suggests the potential effectiveness of antiangiogenic agents and mTOR inhibitors in these tumours. Since all efforts to establish the cell lines derived from human pheochromocytomas and paragangliomas have been unsuccessful (the cells survive but do not proliferate in vitro) [21], a rat pheochromocytoma PC12 cell line was chosen for our studies. PC12 line has been used for studying the mechanism of actions of different growth 
and trophic factors for many years. It was revealed that NGF (nerve growth factor) and bFGF caused differentiation (neurite outgrowth), whereas EGF (epidermal growth factor) stimulated the proliferation of PC12 cells. These effects were dependent on the MAPK (mitogen activated protein kinases) and/or mTOR signalling pathways [22, 23]. PC12 cells have also been shown to synthesise several growth factors, e.g. NGF, bFGF, VEGF [5, 24, 25], as well as to possess NGF, EGF, FGF and VEGF receptors [26-28].

Although IFN- $\alpha$ is an alternative line treatment in some neuroendocrine tumours [29], it has not been used in pheochromocytoma therapy so far $[2,8,9]$. The influence of IFN- $\alpha$ on pheochromocytoma has not been estimated in experimental conditions either. Thus, we have shown for the first time that IFN- $\alpha$ at the concentration of $10^{5} \mathrm{U} / \mathrm{mL}$ caused strong pheochromocytoma PC12 cell growth inhibition, inducing apoptosis as well as arresting the cell cycle in G0/G1 phase. The results confirmed the complex action of IFN- $\alpha$, which potentially included prolongation of the cell cycle time [30], enhancement of apoptosis [31] and modulation of expression of FGF-2 [32] and VEGF in different malignant cells [33].

Similarly, the slight inhibitory effect of rapamycin $\left(10^{-5}-10^{-8} \mathrm{M}\right)$ on PC12 cell growth observed in our study was probably also evoked by multitargeted activity of this drug. Rapamycin, as an mTOR inhibitor, has been shown to block the signalling pathways for many growth factors [3], including those whose receptors are expressed on PC12 cells (VEGF, bFGF, NGF, EGF). Our results remain in agreement with other studies, in which rapamycin at concentrations of $10^{-5}-10^{-9} \mathrm{M}$ inhibited PC12 cell proliferation in $48 \mathrm{~h}$ culture [34].

These facts encourage further studies in this field and suggest that mTOR inhibitors could be not only an alternative treatment in PNETs (everolimus - approved by FDA), but possibly also in malignant pheochromocytoma [35].

The application of VEGF receptor inhibitors in the therapy of different neoplasms gave divergent results. Although the administration of SU5416 resulted in reduction of the growth of different xenografted tumours in mice, it did not inhibit the growth of a variety of neoplastic cells in vitro [36]. In our study, SU5416 at the concentration of $10^{-5} \mathrm{M}$ slightly inhibited the proliferation of PC12 cells. Similarly, sunitinib (a derivative compound of SU5416) markedly induced apoptosis of PC12 cells, initially exerting its apoptotic effect through the inhibition of VEGFR-2, followed by reduction of its downstream effectors (including AKT/mTOR/S6K1) and leading to inhibition of the antiapoptotic molecule Bcl-2 and activation of the proapoptotic molecule BAD [37]. Moreover, sunitinib also gave encouraging results in preliminary studies in patients with malignant pheochromocytoma
[8]. Thus, our results together with other studies suggest that tyrosine kinase inhibitors are a promising group of agents in the therapy of these tumours.

It is interesting that despite the expression of VEGF receptors on PC12 cells, VEGF used in a wide range of concentrations did not affect PC12 cell growth in our study. This is in accordance with the study of other authors, in which no functional effects of VEGF on PC12 cell proliferation or on neurite formation were observed [28]. On the other hand, it has been confirmed that angiogenesis and tumour size in xenotransplanted PC12 cells in mice are VEGF-dependent and inhibited by treatment of anti-VEGF antibodies [5]. These facts suggest that VEGF did not affect PC12 cell growth directly, but indirectly contributed to the growth of xenografted PC12 tumour in vivo by stimulation of angiogenesis. These observations can also explain the fact that in our experiments endostatin, which acts mainly by blocking VEGF/VEGFR signalling [38], does not have any effect on the growth of PC12 cell line. Moreover, other authors did not show a direct binding of endostatin to the PC12 cell surface [28, 39], suggesting the absence of receptors for endostatin in this cell line.

Although GHRHR (GHRH receptor) has been shown to be present in human benign (higher expression) and malignant (lower expression) pheochromocytomas, it has not been demonstrated in PC12 cells [40]. This could explain the lack of antiproliferative activity of JV1-36 in our experiments. However, the effectiveness of GHRH inhibitors is still worthy of being assessed in different pheochromocytoma/paraganglioma models.

In conclusion, although PC12 pheochromocytoma cells express receptors which could be potentially sensitive to antiangiogenic treatment, many agents evaluated in this study did not act directly as anti-mitogenic factors on PC12 cell growth in vitro. IFN- $\alpha$ mTOR and tyrosine kinase inhibitors as multitarget drugs turn out to be more effective than agents selectively blocking only pathways typical for angiogenic factors, and they seem to be drugs of sufficient interest to justify further studies.

Thus, considering the unsatisfactory efficacy of the traditional therapeutic methods in patients with metastatic pheochromocytoma, the results of our preclinical studies indicate that antiangiogenic agents and mTOR inhibitors might comprise a new therapeutic option in clinical use.

\section{References}

1. Tischler AS. Pheochromocytoma and extra-adrenal paraganglioma: updates. Arch Pathol Lab Med 2008; 132: 1272-1284.

2. Parenti G, Zampetti B, Rapizzi E, Ercolino T, Giachè V, Mannelli M. Updated and new perspectives on diagnosis, prognosis, and therapy of malignant pheochromocytoma/paraganglioma. J Oncol. 2012; 2012: 872713. DOI: $10.1155 / 2012 / 872713$.

3. Konings IR, Verweij J, Wiemer EA et al. The applicability of mTOR inhibition in solid tumors. Curr Cancer Drug Targets 2009; 9: 439-450. 
4. Folkman J. What is the evidence that tumors are angiogenesis dependent? J Natl Cancer Inst 1990; 82: 4-6.

5. Zielke A, Middeke M, Hoffmann S et al. VEGF-mediated angiogenesis of human pheochromocytomas is associated to malignancy and inhibited by anti-VEGF antibodies in experimental tumors. Surgery 2002; 132: 1056-1063.

6. Middeke M, Hoffmann S, Hassan I et al. In vitro and in vivo angiogenesis in PC12 pheochromocytoma cells is mediated by vascular endothelial growth factor. Exp Clin Endocrinol Diabetes 2002; 110: 386-392.

7. Favier J, Plouin PF, Corvol P, Gasc JM. Angiogenesis and vascular architecture in pheochromocytomas: distinctive traits in malignant tumors. Am J Pathol 2002; 161: 1235-1246.

8. Fassnacht M, Kreissl MC, Weismann D et al. New targets and therapeutic approaches for endocrine malignancies. Pharmacol Ther. 2009; 123: 117-141.

9. Grogan RH, Mitmaker EJ, Duh QY. Changing paradigms in the treatment of malignant pheochromocytoma. Cancer Control 2011; 18: 104-112.

10. Samant RS, Shevde LA. Recent advances in anti-angiogenic therapy of cancer. Oncotarget 2011; 2: 122-134.

11. Capdevila J, Salazar R, Halperín I et al. Innovations therapy: mammalian target of rapamycin (mTOR) inhibitors for the treatment of neuroendocrine tumors. Cancer Metastasis Rev 2011; 30: S27-S34.

12. Siejka A, Lawnicka H, Melen-Mucha G et al. Antineoplastic action of growth hormone-releasing hormone (GHRH) antagonists. Recent Pat Anticancer Drug Discov 2012; 7: 56-63.

13. Arora A, Scholar EM. Role of tyrosine kinase inhibitors in cancer therapy. J Pharmacol Exp Ther 2005; 315: 971-979.

14. Turner HE, Harris AL, Melmed S et al. Angiogenesis in endocrine tumors. Endocr Rev 2003; 24: 600-632.

15. O'Reilly MS, Boehm T, Shing Y et al. Endostatin: an endogenous inhibitor of angiogenesis and tumor growth. Cell 1997; 88: 277-285.

16. Xie L, Duncan MB, Pahler J et al. Counterbalancing angiogenic regulatory factors control the rate of cancer progression and survival in a stage-specific manner. Proc Natl Acad Sci U S A 2011; 108: 9939-9944.

17. Kulke MH, Bergsland EK, Ryan DP et al. Phase II study of recombinant human endostatin in patients with advanced neuroendocrine tumors. J Clin Oncol 2006; 24: 3555-3561.

18. Decatris M, Santhanam S, O'Byrne K. Potential of interferon-alpha in solid tumours: part 1. BioDrugs 2002; 16: 261-281.

19. Brouty-Boyé D, Zetter BR. Inhibition of cell motility by interferon. Science 1980; 208: 516-518.

20. Ribatti D. Endogenous inhibitors of angiogenesis: a historical review. Leuk Res 2009; 33: 638-644.

21. Tischler AS, Powers JF, Alroy J. Animal models of pheochromocytoma. Histol Histopathol. 2004; 19: 883-895.

22. Potente M, Gerhardt H, Carmeliet P: Basic and therapeutic aspects of angiogenesis. Cell 2011; 146: 873-887.

23. Kawamata T, Yamaguchi T, Shin-ya $\mathrm{K}$ et al. Divergence in signaling pathways involved in promotion of cell viability mediated by bFGF, NGF, and EGF in PC12 cells. Neurochem Res 2003; 28: 1221-1225.

24. Raffioni S, Bradshaw RA. Activation of phosphatidylinositol 3-kinase by epidermal growth factor, basic fibroblast growth factor, and nerve growth factor in PC12 pheochromocytoma cells. Proc Natl Acad Sci U S A 1992; 89: 9121-9125.
25. Gill JS, Schenone AE, Podratz JL et al. Autocrine regulation of neurite outgrowth from PC12 cells by nerve growth factor. Brain Res Mol Brain Res 1998; 57: 123-131.

26. Renaud F, Desset S, Oliver L et al. The neurotrophic activity of fibroblas growth factor 1 (FGF1) depends on endogenous FGF1 expression and is independent of the mitogen-activated protein kinase cascade pathway. J Biol Chem 1996; 271: 2801-2811.

27. Groot M, Boxer LM, Thiel G. Nerve growth factor- and epidermal growth factor-regulated gene transcription in $\mathrm{PC} 12$ pheochromocytoma and INS-1 insulinoma cells. Eur J Cell Biol 2000; 79: 924-935.

28. Foehr ED, Raffioni S, Fuji R et al. FGF signal transduction in PC12 cells comparison of the responses induced by endogenous and chimeric receptors. Immunol Cell Biol 1998; 76: 406-413.

29. Berger I, Stahl S, Rychkova N et al. VEGF receptors on PC12 cells mediate transient activation of ERK1/2 and Akt: comparison of nerve growth factor and vascular endothelial growth factor. J Negat Results Biomed 2006; 5: 8 .

30. Santhanam S, Decatris M, O'Byrne K. Potential of interferon-alpha in solid tumours: part 2. BioDrugs 2002; 16: 349-372.

31. Hanley JP,Haydon GH. The biology of interferon-alpha and the clinical significance of anti-interferon antibodies. Leuk Lymphoma 1998; 29: 257-268.

32. Barber GN. The interferons and cell death: guardians of the cell or accomplices of apoptosis? Semin Cancer Biol 2000; 10: 103-111.

33. Singh RK, Gutman M, Bucana CD et al. Interferons alpha and beta down-regulate the expression of basic fibroblast growth factor in human carcinomas. Proc Natl Acad Sci U S A 1995; 92: 4562-4566.

34. von Marschall Z, Scholz A, Cramer T et al. Effects of interferon alpha on vascular endothelial growth factor gene transcription and tumor angiogenesis. J Natl Cancer Inst 2003; 95: 437-448.

35. Parker EM, Monopoli A, Ongini E et al. Rapamycin, but not FK506 and GPI-1046, increases neurite outgrowth in PC12 cells by inhibiting cell cycle progression. Neuropharmacology 2000; 39: 1913-1919.

36. Giubellino A, Bullova P, Nölting S et al. Combined Inhibition of mTORC1 and mTORC2 Signaling Pathways Is a Promising Therapeutic Option in Inhibiting Pheochromocytoma Tumor Growth: In Vitro and In Vivo Studies in Female Athymic Nude Mice. Endocrinology. 2013; 154: 646-655. Epub 2013 Jan 10.Bridges EM, Harris AL. The angiogenic process as a therapeutic target in cancer. Biochem Pharmacol 2011; 81: 1183-1191.

37. Fong TA, Shawver LK, Sun L et al. SU5416 is a potent and selective inhibitor of the vascular endothelial growth factor receptor (Flk-1/KDR) that inhibits tyrosine kinase catalysis, tumor vascularization, and growth of multiple tumor types. Cancer Res 1999; 59: 99-106.

38. Saito Y, Tanaka Y, Aita Y et al. Sunitinib induces Apoptosis in Pheochromocytoma Tumor Cells by Inhibiting VEGFR2/AKT/mTOR/S6K1 Pathways Through Modulation of Bcl-2 and BAD. Am J Physiol Endocrinol Metab 2012; 302: E615-625.

39. Abdollahi A, Hahnfeldt P, Maercker C et al. Endostatin's antiangiogenic signaling network. Mol Cell 2004; 13: 649-663.

40. Al Ahmad A, Lee B, Stack J et al. Endostatin binds nerve growth factor and thereby inhibits neurite outgrowth and neuronal migration in-vitro. Brain Res 2010; 1360: 28-39.

41. Ziegler CG, Brown JW, Schally AV et. al. Expression of neuropeptide hormone receptors in human adrenal tumors and cell lines: antiproliferative effects of peptide analogues. Proc Natl Acad Sci U S A 2009; 106: 15879-1584. 